\title{
AS PARTICIPAÇÕES INDÍGENAS NAS GUERRAS NO CABO DO NORTE
}

\section{INDIGENOUS PARTICIPATION IN WARS IN THE NORTHERN CAPE}

\author{
Bruno Rafael Machado Nascimento ${ }^{1}$
}

\begin{abstract}
RESUMO: Este artigo tem objetivo de desvelar as agências indígenas nos conflitos entre portugueses, holandeses, ingleses e irlandeses pela conquista do Cabo do Norte (parte do atual Estado do Amapá) na primeira metade do século XVII. A partir da leitura histórica e antropológica das fontes, percebeu-se como os ameríndios criaram táticas de sobrevivência em contextos desfavoráveis, e como os europeus foram dependentes dessas sociedades que conheciam muito bem a Amazônia, sobretudo, nas guerras por controle do território. Demonstra-se como as alianças com as populações nativas e os usos de seus guerreiros em combates foram decisivas para as vitórias ou derrotas dos colonizadores.
\end{abstract}

PALAVRAS-CHAVE: Agências indígenas; Guerras; Fortificações.

ABSTRACT: This article aims to reveal the indigenous agencies in the conflicts between Portuguese, Dutch, English and Irish over the conquest of the Northern Cape (part of the current State of Amapá) in the first half of the 17th century. From the historical and anthropological reading of the sources, it was noticed how the Amerindians created survival tactics in unfavorable contexts, and how Europeans were dependent on those societies that knew the Amazon very well, especially in the wars for control of the territory. It shows how the alliances with the native populations and the uses of their warriors in combat were decisive for the victories or defeats of the colonizers.

KEYWORDS: Indigenous agencies; Wars; Fortifications.

\footnotetext{
* Este artigo é fruto das inquietações intelectuais do autor a respeito das ausências de pesquisas historiográficas que refletissem sobre as participações indígenas nas guerras do Cabo do Norte. Esse anseio fez-me buscar fontes que indicassem sinais e indícios das ações dos ameríndios nos combates na região do atual Estado do Amapá. Não contou com financiamento.

${ }^{1}$ Mestre em Ensino de História (PROFHISTÓRIA-UNIFAP), professor de História da Secretaria Estadual de Educação do Estado do Amapá e professor substituto no colegiado de História da UNIFAP. E-mail: professorbrunohistoria8@gmail.com
} 


\section{Considerações iniciais}

Este artigo visa compreender as relações entre europeus e indígenas durante as guerras pela posse do "Cabo do Norte" (parte do atual Estado do Amapá) na primeira metade do século XVII. A partir das análises da documentação produzida por navegadores, agentes do Estado e religiosos buscou-se perceber como se deu a participação dos diversos sujeitos nativos nos conflitos envolvendo portugueses, irlandeses, holandeses e ingleses. Destaca-se que devido à natureza das fontes este estudo apresenta limites, pois elas são lacunares e as representações sobre os povos ameríndios são muitas vezes estereotipadas. Ademais, os escritos elaborados pelos autores buscaram justificar a colonização, a catequese, exploração comercial, o controle do território e até benesses aos militares devido seus serviços prestados às coroas ibéricas.

De qualquer forma, há presenças indígenas nas fontes históricas que tratam dos conflitos entre as nações europeias no Cabo do Norte. Em geral, os nativos são apresentados somente como aliados ou inimigos nas guerras. A historiografia tradicional obliterou as ações desses agentes históricos e apenas os tratou como sujeitos passivos ou meras vítimas dos processos históricos (CUNHA, 1998). John Manuel Monteiro (1999, p. 238) precisou a questão:

Não há como negar que as sociedades nativas de fato sofreram reveses monumentais diante do impacto fulminante do encontro - na verdade, encontrão - com a expansão europeia. No entanto, reduzir essa experiência à simples caracterização das sociedades como vítimas das iniquidades dos brancos é cometer mais uma injustiça, que se soma a tantos outras. Há boas razões políticas para insistência nessa imagem: afinal, é assim que os movimentos indígenas contemporâneos e os movimentos de apoio aos direitos dos índios têm construído o quadro dramático que busca sensibilizar o público diante das reivindicações de reparações pelos séculos de injustiça, expropriação e violência. Porém, essa perspectiva oculta os múltiplos processos históricos de questionamento, negação e reelaboração de identidades indígenas que informavam e direcionavam as maneiras pelas quais diferentes segmentos nativos se posicionavam diante da nova ordem que começou a se instaurar com a chegada dos primeiros navegantes portugueses, há quinhentos anos. 
A citação do historiador sintetiza a perspectiva atual da nova história indígena que em hipótese alguma nega as consequências desastrosas da conquista europeia, no entanto, valoriza as negociações, enfrentamentos, reelaborações das identidades indígenas e não as toma como cristalizadas. Em outras palavras, mesmo que em relações de poder assimétricas, os nativos fizeram as escolhas possíveis a partir dos seus interesses.

Para as análises históricas dos documentos exige-se do historiador certa sensibilidade antropológica para perceber as ações e interesses dos indígenas. Maria Regina Celestino de Almeida (2012) propõe a leitura históricoantropológica das fontes. Essa leitura configura-se na estreita relação entre História e Antropologia com o intuito de problematizar a documentação em relação às concepções eurocêntricas e preconceituosas dos colonizadores. Neste aspecto as indicações de Carlo Ginzburg (2001) são preciosas. Cabe ao pesquisador decifrar aquilo que não está explícito e, por isso, tal como um detetive, examinar os pormenores e indícios imperceptíveis para a maioria das pessoas. Ao analisar os escritos sobre as guerras entre os europeus no Cabo do Norte, precisa atentar-se aos dados marginais, aqueles considerados menores, para poder perceber as diversas ações e estratégias dos ameríndios: "nesse sentido, o historiador é comparável ao médico, que utiliza os quadros nosográficos para analisar o mal específico de cada doente. E, como o do médico, o conhecimento histórico é indireto, indiciário e conjetural" (GINZBURG, 2001, p. 157).

Após esta reflexão sobre a valorização das agências indígenas, é necessário situar geograficamente o que se compreende como Cabo do Norte. No século XVII, essa região era demasiadamente imprecisa nas fontes portuguesas. Toma-se como exemplo o relatório que fez o capitão André Pereira dando conta das conquistas no rio Amazonas em 1616:

Primeiramente, depois que o capitão mor Alexandre Moura deu fim no Maranhão a o que tocava ao serviço del rei em deitar fora a o inimigo como (o) fez e tendo a terra pacífica e povoadas as fortalezas como lhe pareceu necessário, pois por obra mandar fazer este novo descobrimento do grande rio das Amazonas, e para também se saber o que havia no cabo do 
Norte, conforme a ordem que para isso levava do governador geral do Brasil Gaspar de Souza; e assim mandou 150 homens em três companhias e por capitão mor delas a Francisco Caldeira de Castelo Branco em três embarcações (Relação que fez o capitão André Pereira sobre o rio das Amazonas e terras circundantes apud SARAGOÇA, Lucinda, 2000, p. 228) ${ }^{2}$.

Nesse relatório, o militar cita que entraram no "rio das Amazonas" e também relata a necessidade de saber "o que havia no cabo do Norte". Em 1616, os portugueses haviam fundado Belém, e esse ainda era o momento de conhecimento da região que era praticamente desconhecida. Essa é a razão da imprecisão que se prolongou por muito tempo, mas se tinha consciência que era a região setentrional da Amazônia. O Cabo do Norte é um acidente geográfico que fica na costa do atual Amapá e que no período colonial servia de referência aos navegadores que encaravam a foz do Amazonas. Desde o século XVI, os cartógrafos já identificavam esse cabo, o que indica que ele era conhecido por navegadores de diversas nacionalidades. Observe o recorte do mapa elaborado por Levino Hulsius (nascido na Bélgica, mas viveu na Holanda) em 1599 intitulado "nova et exacta delineatio America partis australis que est : Brasilia, Caribana, Guiana regnum novum, Castilia del Oro, Nicaragua, Insula Antillas et Peru, et sub Tropico Capricorni, Chile, Rio della Plata, Patagonu[m], \& Fretu[m] Magellanicu[m]". Nele aparece "C do Norte" ao lado do "Rio de las Amazonas".

\footnotetext{
${ }^{2}$ Várias citações documentais foram extraídas do livro da Lucinda Saragoça (2000) que é uma obra em que a autora basicamente se propôs a transcrever documentos do século XVII com um corpus documental com quase 300 páginas.
} 
Mapa 1 - Mapa recortado de Levino Hulsius (1599)

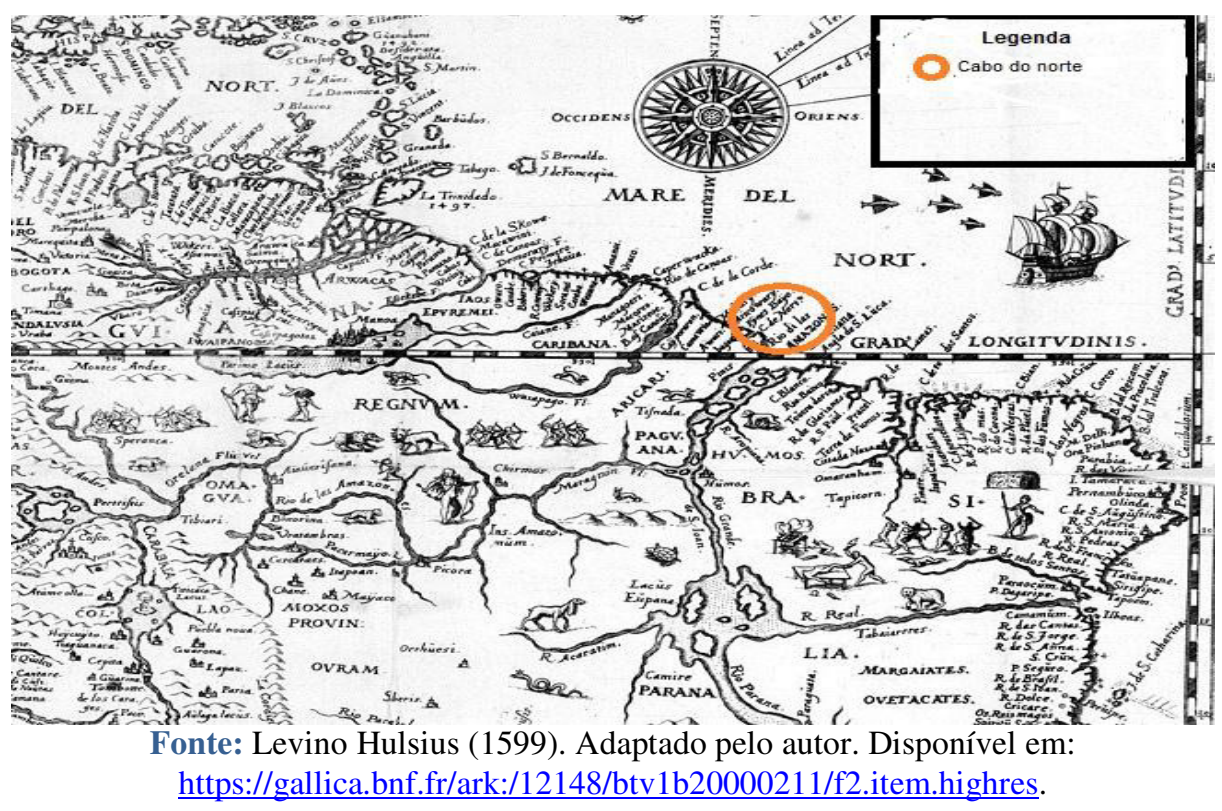

Cabe outro esclarecimento sobre o Cabo do Norte. Em 14 de junho de 1637, o rei da União Ibérica D. Felipe IV concedeu a Bento Maciel Parente uma capitania privada intitulada também Cabo do Norte. A carta de doação delimitava o território:

Que tem pella costa do mar trinta te quarenta legoas de distrito que se contão do dito cabo ate o Rio de Vicente Pinzon onde entra a repartição dos Índias do Reino de Castella e pella terra dentro Rio das Amazonas arriba da parte do canal que vai sair ao mar oitenta para cem legoas ate o Rio dos tapujusus (Carta de doação a Bento Maciel Parente apud DA SILVA, 2010: 490-491).

Segundo Arthur Reis (1949), Tapujusus era o rio Surubiú que na confluência com o Amazonas, banhava Alenquer. Ele cita os núcleos populacionais, "dentro da área que abrangia já existiam núcleos de povoamento: os povoados de Gurupatuba e Surubiú, hoje Monte Alegre e Alenquer" (REIS, 1949, p. 23). Essa vila, portanto, pode ser considerada o limite a oeste da dita capitania. Segundo o padre João Felipe Bettendorff (1990, p. 31), que escreveu sua crônica no final do século XVII a capitania corresponderia ao território: 
Defronte da Capitania de Gurupá que é d'El-Rey, está de outra banda do rio das Amazonas a Capitania do Donatario Bento Maciel, chamada comumente Cabo do Norte. Corre esta Capitania pela costa até o rio Vicente Pinson, e para o poente pelo rio a riba até por cima da aldêa de Gurupatiba, comprehende os Tucujus com suas aldeas, o rio Parú com as suas, e pelo rio das Amazonas para cima a aldêa de Jagoacuara, a aldêa de Urubuquara, e aldêa de Gurupatiba. Para parte Norte tem a fortaleza do Macapá que o Governador Antonio de Albuquerque Coelho de Carvalho mandou fazer por ordem de Sua Majestade, já foi tomada uma vez pelos Francezes em o anno de 1697, com da o Parú, como depois se dirá mais largamente em seu logar.

O rio Vicente Pinzon (Oiapoque) era a fronteira administrativa mais ao norte. O jesuíta Bettendorff citou as diversas aldeias que faziam parte da capitania e que, além disso, eram compostas por missionários que tentavam catequizar os indígenas. Este estudo não abrange as guerras em todo o território da capitania, mas na região que corresponde ao atual Estado do Amapá, ou seja, a oeste o limite é o rio Jari, ao norte o Oiapoque e a leste o oceano Atlântico.

\section{Alguns apontamentos sobre as guerras indígenas}

O Cabo do Norte foi marcado por conflitos que envolveram portugueses, holandeses, ingleses, irlandeses e grupos indígenas na primeira metade do século XVII. Após a saída dos franceses do Maranhão e a fundação de Belém em 1616 coube aos portugueses enfrentar diversos povos na conquista e expansão do território. Outras nações europeias mantinham relações econômicas, políticas e militares com os indígenas antes da chegada dos lusos. Em toda a América portuguesa a negociação com os nativos foi fundamental para colonização, pois sem eles o fracasso era certo (ALMEIDA, 2013). Na Amazônia colonial os ameríndios foram as "mãos" e "pés" dos colonizadores principalmente até 1755 , com a criação da companhia de comércio do Grão Pará e Maranhão, quando a vinda de africanos escravizados foi incentivada com maior intensidade (COELHO, 2008). Os outros europeus instalaram as feitorias, fortes e plantações com a colaboração das lideranças indígenas que tornou essa 
realidade possível, pois os nativos indicavam os lugares, as madeiras e onde se devia pescar. Foram os guias, os remadores, pescadores, caçadores, produtores de canoas, trabalhadores e, consequentemente, os principais guerreiros nos combates.

As guerras faziam parte das culturas ameríndias muito antes da chegada dos colonizadores, e os europeus se aproveitaram disso para conseguir vantagens. Mas também os indígenas souberam tirar proveito. Exemplo clássico é o dos Tupinambá (um subgrupo Tupi que inclui vários outros). Florestan Fernandes (2006) afirma que entre esse grupo a guerra possuía uma função social importante para manutenção da sociedade. Era o elemento básico de organização, reprodução e coesão social. Manuela da Cunha e Eduardo Viveiros de Castro (1985) asseveram que a vingança era o fator mais importante nas guerras dos Tupinambá. Para o ritual antropofágico, participavam os membros das aldeias e os aliados, mesmo que não participassem diretamente do conflito. $\mathrm{O}$ objetivo da guerra não era matar, mas capturar para que no momento oportuno a vingança se consumasse e perpetuasse no tempo passado e futuro.

Era principalmente por meio da guerra que os líderes indígenas aumentavam seu prestígio perante a comunidade. Os combates, além de honra e glória, promoviam laços de solidariedade entre os povos aliados (ALMEIDA, 2010). Assim, "Os Tupinambás não pretendiam dominar nem negar o outro, mas vivenciá-lo, relacionando-se intensamente com ele. Daí a receptividade e abertura ao contato que tanto surpreendeu os europeus e possibilitou a colonização" (ALMEIDA, 2010, p. 38).

Nos primeiros contatos, os europeus foram inseridos nas redes de relações indígenas que possuíam outros significados e fronteiras. No decorrer do tempo os sentidos atribuídos pelos nativos às guerras e mercadorias europeias foram sendo modificados e ressignificados. Ademais, eles também modificaram os europeus que aprenderam a navegar pelos rios, igarapés e andar pelas matas da Amazônia colonial. No entanto, não se podem reduzir os interesses das populações indígenas apenas aos objetos europeus que entre elas 
recebiam outros significados e utilidades. Um machado de ferro, por exemplo, facilitava e otimizava o trabalho nas aldeias; e miçangas adornavam mulheres e lideranças indígenas aumentando seu poder simbólico no interior da comunidade. Mas qual o interesse deles nas guerras para além das questões culturais? A resposta é simples, formar alianças com os europeus para se fortalecerem e assim se protegerem ou avançarem sobre os grupos rivais (ALMEIDA, 2010).

\section{As guerras no Cabo do Norte nos inícios do século XVII}

A historiografia tradicional ao tratar sobre as guerras no Cabo do Norte no século XVII sempre buscou exaltar as ações dos "corajosos" e "valorosos" militares portugueses na expulsão dos "estrangeiros" e conquista do território (REIS, 1949; BETTENDORF, 1990; BAENA, 1838; SARAGOÇA, 2000; BERREDO, 1749). Dessa maneira, os indígenas foram tratados apenas como meros joguetes ao dispor dos interesses dos colonizadores. Para Wania Alexandrino (2018), a história militar deixou para esses sujeitos o caráter secundário, ou seja, aparecem apenas como auxiliares em diligências militares, quando aparecem. Segundo a referida autora, os indígenas foram fundamentais para conquista e defesa da colônia.

É importante saber que o forte do Torrego foi tomado dos holandeses em 1629 e que em 1631 o forte inglês do Felipe, localizado entre os rios Matapi e Anauerapucu, foi conquistado pelo capitão-mor Jacome Raimundo de Noronha (REIS, 1993), mas interessa, sobremaneira, como os ameríndios participaram. Eles foram efetivamente o maior contingente e merecem ter as suas agências analisadas, pois sem a aliança com eles, portugueses, holandeses, irlandeses e ingleses não conseguiriam se instalar no Cabo do Norte.

$\mathrm{Na}$ 'relação' do capitão André Pereira, escrita em 1616, já se sabia da presença de holandeses e franceses no Cabo do Norte onde possuíam feitorias e plantavam a cana de açúcar que era enviada à Europa. No rio Amazonas, os holandeses foram incluídos nas redes de comércio dos indígenas: 
As mercadurias que este gentio vende aos Olandeses são algodão, tinta de oroco que he como gram, algûa pita, e este pao cotiara, como outras sortes de madeiras que não faltão; tabaco; dizem que ha castores, e este capitão franzes que ali nos serve de lingoa dize lhe derão hûa pelle de hum mui fina (Relação que fez o capitão André Pereira sobre o rio das Amazonas e terras circundantes apud SARAGOÇA, Lucinda, 2000, p. 229).

Os ameríndios negociavam diversos produtos como, por exemplo, o urucum, algodão, tabaco e madeiras, com os holandeses, que eram vendidos na Europa gerando bastante lucro. Destaque também na citação para o 'lingoa' (conhecedor de línguas nativas), francês que fazia a mediação entre os portugueses e indígenas. Esse francês que havia fugido do Maranhão servia também de guia e confessou que havia 'flamengos' que estavam na região para aprender a língua. Essa foi uma prática comum para facilitar a negociação entre os europeus e ameríndios, não apenas do ponto de vista comercial, mas também como aliados nas guerras. Os documentos que tratam da presença de holandeses e ingleses no Cabo do Norte são abundantes, o que demonstram os fortes laços dessas nações com os nativos. No documento sobre as coisas do Grão-Pará, destinado ao rei Felipe II e escrito pelo militar Manuel de Sousa d'Eça afirmase que no Cabo do Norte: "vão todos os annos ingresses e Olandeses ao resgate de tabaco, e de alguas tintas" (Sobre as coisas do Grão-Pará apud SARAGOÇA, 2000, p. 235).

Os ameríndios definitivamente haviam inserido os ingleses e holandeses em suas redes de relações. Por outro lado, europeus instalaram feitorias onde todos os anos mandavam navios carregados. Mas o que fez os nativos preferirem, ao menos neste momento de conquista, os holandeses, irlandeses e ingleses? Para Manuel d'Eça, os portugueses tratavam mal os 'gentios' e outros europeus: "lhes dão o que hão mister em abundância, e os tratão melhor, e com mais verdade que he o que querem" (Sobre as coisas do Grão-Pará apud SARAGOÇA, 2000, p. 235). Percebe-se que os indígenas jogavam de acordo com os seus próprios interesses fazendo a leitura da realidade. Eles eram mal tratados por determinado grupo e, por isso, os repeliam. Por outro lado, outros 
grupos lhes ofereciam materiais que interessavam. Nestas circunstâncias nada favoráveis para os portugueses, Manuel d'Eça propunha a vinda de um padre da Companhia de Jesus chamado Domingos Roiz que era um língua, ou seja, dominava determinada língua indígena para "pacificar" e converter, para assim conseguir aliados. Ademais, pediu soldados e uma profusão de armamentos para expulsão dos inimigos no Cabo do Norte.

\section{Conflitos entre holandeses, indígenas e portugueses}

Para facilitar a compreensão do leitor, serão divididas em seções as análises das guerras entre portugueses, indígenas, ingleses e holandeses. Isso é um esforço didático, pois diversas vezes os outros europeus estavam juntos no mesmo forte, por exemplo, num forte holandês o responsável era um irlandês. Em várias ocasiões, embarcações que partiam da Holanda estavam repletas de ingleses e abasteciam fortes e feitorias de diversas nacionalidades, pois a marinha mercantil holandesa era a mais poderosa no século XVII. A presença de exploradores de diversas nacionalidades trabalhando a serviço de outro reino não era incomum na colonização da América. Isso significa que mercenários se ofereciam para trabalhar a serviço de determinado reino, mas havia disputas e projetos de cada um dos reinos na região amazônica.

Holandeses, ingleses e irlandeses, a partir de 1600 no delta amazônico, implantaram várias feitorias e fortificações para comercializarem com as populações indígenas. Levaram da região madeiras, peixes-boi, gomas, urucum, cacau que eram vendidos no mercado europeu, mas com o decorrer do tempo eles resolveram, com o apoio do trabalho indígena, cultivar tabaco e cana em pequenos assentamentos. Para a região do atual Amapá e em toda Amazônia portuguesa, assim como, em outros territórios americanos na primeira metade do século XVII, houve ação de uma pequena companhia holandesa chamada de Guiaansche Compagnie que fretou navios para comercializar na região, principalmente no Suriname. Segundo Lodewijk Hulsman (2016, p. 41), “os navios holandeses abasteciam as feitorias dos ingleses e irlandeses na banda 
ocidental e transportavam para Europa". Além disso, enchiam seus navios com produtos da Amazônia o que geravam bastantes lucros.

Inicialmente, implantaram feitorias (espécie de armazéns fortificados eram levantados próximos às moradias dos nativos), pois pagavam para os indígenas construírem casas e limparem as roças, mas depois evoluiu para pequenas plantações de tabaco, algodão e urucum. Para tanto, utilizavam o trabalho indígena em que os batavos ofertavam mercadorias manufaturadas, por exemplo, machados, contas de vidro, tesouras, facões e armas. Esse comércio foi importante e lucrativo, pois a relação com os indígenas era considerada amigável, o que exigia poucos gastos com armamento, fortalezas e soldados gerando bons dividendos (HULSMAN, 2011). Os produtos levados do Cabo do Norte para Europa eram bastante valorizados, principalmente as madeiras e o tabaco. Fato interessante era que para facilitar o comércio com os indígenas, os holandeses levavam indígenas para aprender a sua língua. Estes, por sua vez, retornavam e exerciam a função de intermediários (HULSMAN, 2011).

Barão do Rio Branco afirma sobre a presença holandesa no "Amapá", "por volta de 1610, os holandeses possuíam feitorias e postos fortificados na região dos Tucujus, entre o Jari e o Macapá, na margem setentrional do Amazonas" (RIO BRANCO, 2012, p. 107). Isso significa que eles estabeleceram vários pontos comerciais e militares nesse território com o objetivo de explorar comercialmente. Nas fortificações, por meio do trabalho indígena, criaram-se vários assentamentos onde se plantavam e exportavam para Europa. Alírio Cardoso assevera que o estilo de construções dos pequenos fortes neerlandeses na Amazônia: "eram de taipa de pilão reforçada com madeira de lei e algumas poucas pedras, a mesma técnica utilizada na maioria das construções portuguesas na Amazônia seiscentista que contou sempre com larga utilização do trabalho indígena" (CARDOSO, 2015, p. 47).

Portanto, os holandeses criaram pequenos fortes no Cabo do Norte durante o século XVII com o objetivo não apenas militar, mas principalmente comercial. Os indígenas foram fundamentais, pois sem eles a colonização europeia era impossível de acontecer. Por meio da exploração do trabalho, os 
ameríndios extraíam e plantavam vários produtos que foram vendidos na Europa. Além disso, as alianças com as populações nativas foram fundamentais também na defesa dos fortes e nas lutas contra os portugueses. Todos os europeus buscavam essas alianças para obter alguma chance de vitória, pois os ameríndios conheciam a região e usavam as táticas de guerra mais apropriadas para a realidade amazônica.

Em 1625, Luis Aranha de Vasconcelos informou ao rei Felipe III que tomou dois fortes dos holandeses no rio Xingu que eram conhecidos como Maturu e Nassau. Destaca-se a dependência em relação aos indígenas, pois para contar com ajuda deles em diversas atividades, os neerlandeses tiveram que negociar e oferecer vestidos, camisas, toalhas, guardanapos. Os europeus comercializavam com os nativos: "algodão, pita e madeiras de valor e outras couzas de que por Conficão dos olandeses se mostra carregaren doze athe quinze navios cada anno" (Luis Aranha Vasconcelos informa Filipe III sobre o descobrimento que fez do rio das Amazonas e Cabo do Norte, 1625 apud SARAGOÇA, 2000, p. 251). Luis Aranha pediu dinheiro para poder comprar objetos com o intuito de negociar para que os ameríndios os ajudassem na guerra, na construção de trincheiras e fortalezas. Mais uma vez se percebe as agências dos nativos que puderam na medida do possível materializar seus interesses. Esses objetos europeus entravam em circulação nas redes que se espalhavam pela Amazônia e se tornavam adornos e materiais de distinção entre os indígenas. Ou seja, pedras, vestidos, miçangas, camisas foram ressignificadas (HENRIQUE, 2018).

Pedro Teixeira, Pedro da Costa Favela e Jerônimo de Albuquerque conseguiram no mesmo ano destruir o forte holandês Mandiutuba (no Gurupá) que estava localizado na margem direita do Amazonas "e os estabelecimentos ingleses denominados Tilletille e Uarimiuaca, localizados no rio Cajary, afluente do Amazonas pela margem esquerda, fazendo prisioneiros seus sobreviventes" (ALVES FILHO; SOUZA JÚNIOR; BEZERRA NETO, 2001, p. 20-21). Segundo Antônio Ladislau Baena (1838), em 1628, os holandeses fugiram em direção ao rio Felipe e se uniram com os indígenas Tucuju em 
casas-fortes. Constantemente na documentação, faz-se referência à ilha ou local dos Tucujus que era, assim como, o Cabo do Norte uma região não delimitada claramente. Segundo Pablo Ibáñes Bonillo (2015), os portugueses, de maneira imprecisa em princípios do século XVII, utilizavam o termo Tucujus para referir-se à toda região norte que escapava das suas influências, que incluía também a ilha grande de Gurupá, chamada de ilha dos Tucujus na documentação. Para ele, os Tucuju eram um conjunto heterodoxo de grupos assentados na região do Jarí-Cajarí-Maracá, uma zona em que havia influência Tupi, Aruaque e Caribe. Não há certeza sobre a sua língua, mas possivelmente era do tronco Aruaque, apesar de Curt Nimuendaju acreditar que fosse Caribe. Fato é que os holandeses construíram com ajuda dos nativos o forte do Torrego (SARAGOÇA, 2000).

$\mathrm{Na}$ relaçam de vários successos acontecidos no Maranham e Gram Para, assim de paz como de guerra, contra o rebelde Olandes Ingreses e Franceses, e outras nações de autoria do padre Luiz Figueira, impresso em Lisboa no ano de 1631, o religioso narrou as histórias de guerras a partir da perspectiva religiosa. Destacou que a luta não era apenas política e econômica, mas também religiosa. Foi necessário vencer os "hereges" holandeses e ingleses que comercializavam com o "gentio do rio dos Amazonas da banda do norte" (1902, p. 17). Em 1629, narrou o combate contra holandeses no Cabo do Norte:

Vierão em abril de 628, a rio das Amazonas, a onde chamauão o Tucujú; onde se fortificarão, fazendo hum forte de madeira con hûa cava de 20 palmos de alto \& hûa barbacãa de doze palmos dalto, \& 15 de largo de, outros $4 \&$ todo o forte era quadrado. Tinha quatro pedreiros, \& hûa pessa grossa de artelharia. Aly chamauão o gentio, que le fazia fumo, \& comerceauão com elle, \& por serem ali ja antigos os q' dali tinhão ido, lhe sabiam mui bem a língua (Relaçam de vários successos acontecidos no Maranham e Gram Para, assim de paz como de guerra, contra o rebelde Olandes Ingreses e Franceses, e outras nações, 1902, p. 18).

O jesuíta descreve o forte do Torrego e a presença dos indígenas Tucuju que auxiliavam os holandeses. Eram eles que cultivavam o tabaco ao redor da fortificação e negociavam com os europeus. A vantagem dos batavos era que 
comercializavam há bastante tempo e já tinham aprendido a língua, o que facilitava as interações entre mundos distintos. Em 1629 o governador do Maranhão e Grão-Pará, Francisco Coelho de Carvalho, enviou Pedro da Costa para região com trinta ou quarenta soldados portugueses e "800 índios frecheiros" (Relaçam de vários successos acontecidos no Maranham e Gram Para,..., 1902, p. 18). Nota-se a desproporção entre portugueses e indígenas para efetuar a diligência. Os indígenas flecheiros foram fundamentais nos combates em toda Amazônia colonial.

Segundo Almir Diniz (2017), os arcos e flechas formavam as armas mais comuns e, quando em guerras, eram utilizadas as maiores, tanto que chegavam a transpassar um homem ou mesmo qualquer superfície de madeira. Eram tão potentes que chegavam a atingir o oponente a 150 metros de distância. Outra arma era a zarabatana com flechas envenenadas, que ao tocar o inimigo matava em pouco tempo, porém contra os europeus ela não era efetiva devido as roupas e couraças que não permitiam o perfuramento.

Nesse conflito, houve mortos entre holandeses e portugueses. Os lusos tiveram que recuar até Gurupá, pois os indígenas os abandonaram. Padre Luis Figueira assim escreveu:

Os Indios q'hião com os portugueses, vendo os naturaes que acompanhauão os Olandeses, lançararãose a elles, \& os perseguirão fasendo nelles grande matança, desamparando os portugueses, que em desigual número pelejauão com os Olandeses, auendo poucos índios que ajudauão, \& hûns \& outros peleijarão ate que cançados de hûa \& outra parte se forão apartando: \& nossos se achauão já sem poloura, nem pilouros, \& asi se vierão pera a caua, onde estaua o Capitão Pero da Costa com mais gente (Relaçam de vários successos acontecidos no Maranham e Gram Para,..., 1902, p. 19).

Os ameríndios que acompanhavam os lusos foram ao combate contra os nativos que mantinham alianças com os holandeses e deixaram os portugueses em desvantagem. Nesta citação do padre Luis Figueira, percebe-se o quanto dependia dos indígenas não apenas flecheiros em combate, mas também como guias e pilotos pelos rios e igarapés. As técnicas indígenas de combate eram as mais adequadas para a região, e sem esse auxílio seria impossível expulsar o 
inimigo. Sabendo do recuo, o governador do Estado enviou como reforço Pedro Teixeira que contou com a ajuda de soldados e indígenas do Maranhão. A orientação foi que se fizesse o cerco no forte para que os holandeses não fossem socorridos com alimentos pelos nativos e assim se rendessem: "porque sem gentio não se poderião os inimigos conservar muito tempo" (Relaçam de vários successos acontecidos no Maranham e Gram Para,..., 1902, p. 19). Nos arredores dos fortes, os europeus comercializavam com os indígenas que ofertavam, além de mercadorias a serem levadas a Europa, alimentos para sobreviverem. Sem os indígenas, o próprio ato de sobreviver era difícil. Os portugueses sabiam disso e por isso a necessidade bloquear os contatos.

Antes de ir à Gurupá encontrar com Pedro da Costa, Pedro Teixeira passou em Cametá para pegar farinha e juntar mais indígenas aliados com o intuito de reforçar a força militar. A farinha, cuja origem é das culturas ameríndias, era essencial não apenas para alimentação de ameríndios e colonos, mas para pagamentos dos militares. Em muitas ocasiões a farinha era uma condição para que não houvesse revoltas, assim como, o empenho dos ameríndios em guerras e em atividades econômicas (CRUZ, 2016). Dessa forma, o ato de pegar a farinha de mandioca em Cametá não era apenas para garantir o sustento, mas, possivelmente, para manter as "nações" aliadas.

Pedro Teixeira foi com pouco mais de 100 soldados portugueses e 1.600 indígenas flecheiros, "os quaes todos se embarcarão em 98 canoas em busca do inimigo, com suas espias diante em canoas mais ligeiras" (Relaçam de vários successos acontecidos no Maranham e Gram Para,... 1902, p. 20). Os "espias" eram fundamentais na guerra amazônica, pois iam a frente nas canoas mais rápidas para localizarem os inimigos e assim avisar aos europeus com antecedência. Tocavam um tambor feito com troncos de árvore para alarmar os aliados, outras vezes os "espias" ficavam nos altos das árvores para vigiar os rios. A sensibilidade dos nativos em andar pelos rios, matos e a capacidade de enxergar na floresta foi determinante não apenas nas guerras, mas para efetivação da colonização (CARVALHO JÚNIOR, 2017). 
Em setembro de 1629, Pedro Teixeira cercou o forte holandês e construiu trincheiras. Afirmou o padre Luis Figueira que dentro havia muitas casas cobertas com palhas, construídas pelos ameríndios para moradia dos neerlandeses, e que os indígenas que acompanhavam os portugueses lançaram flechas incendiadas para provocar incêndios, mas não teve o efeito esperado. Um indígena que morava nas proximidades do forte e aliado dos holandeses os avisou do ataque. Depois de vários combates e poucos mortos do lado português e muitos dos holandeses, a situação tornou-se favorável para os lusos. O inaciano destacou algo que foi decisivo para vitória: "despois de Sinco ou seis encontros que ouve destes (em hû dos quais se lhe matou hum Indio principal, que era todo seu remedio, porque por sua ordem lhe vinham mantimentos das aldeas), chegarão os inimigos, a estado miserável" (Relaçam de vários successos acontecidos no Maranham e Gram Para,... 1902, p. 20).

O religioso chamou o 'principal' (líder dos indígenas) de 'remédio' para os holandeses, pois era por meio desse líder indígena que os neerlandeses recebiam mantimentos. Assim, a sua morte em combate foi fator determinante para vitória. O designado 'principal' era o indivíduo que exercia sobre determinado grupo indígena um poder político e social persuasivo e menos coercitivo (DOMINGUES, 2000). No processo inicial de colonização, as alianças e cooptações dos 'principais' foram essenciais para conquistas, especialmente, no fornecimento de alimentos para os empreendimentos europeus, assim como em alianças nas guerras. Sabe-se que os colonizadores pressionavam as populações nativas para fornecerem a alimentação e que isso impactou a organização produtiva dos diversos povos.

Como já exposto, os líderes nativos também se aproveitavam das alianças com os europeus para protegerem os seus grupos, vencerem outros povos inimigos e fortalecerem os seus prestígios no seio de suas comunidades. Segundo padre Figueira, o conflito terminou com a rendição dos holandeses e um acordo de paz. James Porcel ou Purcell (irlandês) foi quem governou a fortificação do Torrego e ao final da batalha e foram entregues aos portugueses 
os objetos que estavam no forte; e em seguida ele foi queimado (BERREDO, 1749).

Há outra versão para este combate que culminou com a tomada do Torrego. Ela se encontra no livro editado pela pesquisadora Joyce Lorimer $(1986)^{3}$ em que reuniu diversos documentos sobre a presença europeia na Amazônia. O capitão neerlandês Bernardo Del Carpio chegou ao Cabo do Norte em 1629 para prestar auxílio aos membros da WIC (companhia das Índias Ocidentais) que era uma companhia comercial holandesa privada e explorava a Amazônia. Segundo André Lima (2006), o holandês foi informado pelos indígenas que os portugueses estavam na região e por isso criou o forte do Torrego com um pouco de artilharia e argamassa. Deixou alguns batavos por lá, liderados pelos irlandeses Matthias Omallon e Diego Porcel (James Porcell) que eram os engenheiros. O capitão foi para o interior acompanhado de soldados para apaziguar uma guerra que estava ocorrendo entre os indígenas.

Bernardo Del Carpio afirma que:

Retornou para ajudar seu pessoal com 42 brancos e 10,000 índios, encontrando o inimigo antes mesmo de chegar ao forte juntamente com alguns guerreiros sendo 200 brancos e 7,000 índios. Eles então lutaram, havendo perdas em ambos os lados, o suplicante foi ferido por duas balas e uma flecha, seus índios fugiram abandonando-os a morte. Sem desistir ele e os 42 brancos continuaram a luta e vencendo seus adversários conseguiram uma vitória (LORIMER, 1989:302 apud LIMA, 2006: 221$)^{4}$.

Neste excerto há semelhanças e diferenças com relação ao relato do padre Luis Figueira. Ambos afirmam que houve o primeiro combate e que a vitória foi dos holandeses, mas há uma diferença importante: na narrativa do holandês, eles foram os abandonados pelos indígenas e não os portugueses como narrou o missionário jesuíta. Obviamente que os textos tinham objetivos de exaltação aos colonizadores, no entanto, nas entrelinhas, é perceptível a importante participação dos ameríndios nos combates, tanto que Bernardo Del

\footnotetext{
${ }^{3}$ Obra com o corpus documental é LORIMER, Joyce (Ed.). English and Irish Settlement on the River Amazon 1550-1646. London: Hakluyt Society, 1989.

${ }^{4}$ Essa e outras citações foram extraídas do livro editado por Joyce Lorimer, citadas e traduzidas por André da Silva Lima (2006).
} 
Carpio teria levado uma flechada e conseguido sobreviver. Na versão do holandês, ele capturou dois portugueses e alguns indígenas. Ao saber que eram portugueses os libertou e pediu para que avisassem a Pedro da Costa que não queria guerra (LIMA, 2006).

Pedro Teixeira não aceitou os argumentos e no 'sertão dos Tucujus' chegou ao forte do Torrego, onde fez um cerco até a rendição. Na versão de Bernardo Del Carpio, o português estava com 300 brancos e 15.000 indígenas; e fez um ataque surpresa durante a noite. A companhia de Chichorro foi enviada e tomou o forte (LIMA, 2006). Ataques surpresas não eram uma prática comum dos europeus, mas sim dos guerreiros ameríndios. Essa era a principal técnica militar indígena, e as nações europeias não estavam acostumadas com ela. Os nativos atacavam inclusive à noite com técnica de camuflagem entre as árvores, o que deixava os colonizadores atordoados (CARVALHO JÚNIOR, 2017).

Alguns dias depois da conquista do forte, chegaram à região navios ingleses sob o comando do capitão Roger North para ajudar os 'estrangeiros' e o capitão enfrentou Pedro Teixeira que estava em Gurupá, mas encontraram resistências por parte dos portugueses (SARAGOÇA, 2000). Roger North fugiu com seus companheiros e indígenas aliados; e nas proximidades do Torrego construiu uma fortificação, isto é, no rio Felipe (possivelmente o atual Cajari). Nesses embates, os ameríndios aliados foram decisivos. Destaca-se o que o missionário escreveu sobre um indígena:

Nesta occazião se assinalarão algûs Indios muyto mostrando grande valor nas escaramuças; entre os quais hum chamado Caraguatajuba Potiguar do rio grande indo a hum assalto, vendo no rio tres canoas dos Indios naturais aliados com os Olandeses, toma hûa espada na boca, \& lançase a nado, \& as foi alagando hûa, \& hûa, saindo em terra as frechadas matou muyto delles" (Relaçam de vários successos acontecidos no Maranham e Gram Para,..., 1902, p. 22-23).

Nessa citação, o padre faz um elogio especialmente ao indígena nomeado de Caraguatajuba, destacando a sua coragem em enfrentar os nativos aliados dos portugueses na guerra contra os holandeses. Não pode passar 
despercebido que ele era natural do Nordeste, o que significa que em combates na Amazônia, poderia haver recrutamentos de ameríndios aliados de outras regiões a fim de alcançar o sucesso almejado. Mas por que o religioso fez questão de destacar a bravura desse ameríndio? Imagina-se que a intenção era fazer com que o governador do Estado ou o rei premiasse o nativo. Figueira escreveu:

E em todo este tempo era notavel a força que estes Indios fazião ao Capitão, que os deixasse escalar o forte, que elles se atrevião entrar, mostrandose enfadados da dilação da guerra, querendo logo vir as mãos com os inimigos. Mas o trabalho he que não vem disto nenhum galhardão em nombre de Rey (relaçam de vários successos acontecidos no Maranham e Gram Para, assim de paz como de guerra, contra o rebelde Olandes Ingreses e Franceses, e outras nações, 1902, p. 23).

A valorização do protagonismo dos indígenas neste excerto durante a guerra tinha a intenção de garantir "galhardão" aos aliados dos portugueses. $\mathrm{Na}$ Amazônia colonial, os lusitanos ofereciam mercês aos nativos que prestassem diversos serviços à Coroa como forma de fortalecer alianças, com o objetivo de expandir e consolidar as conquistas. No decorrer do processo histórico, os indígenas começaram a pedir ao rei mercês e benefícios como reconhecimento dos serviços prestados. Almir Diniz (2017, p. 195) assevera que "no Maranhão a política de enobrecimento das lideranças indígenas ligava-se ao firme propósito de conseguir aliados na guerra contra seus inimigos europeus". O enobrecimento de algumas lideranças pelo Estado português gerava o sentimento de diferenciação e privilégio entre os principais que passavam a usar vestimentas próprias, certou grau de autonomia para negociações e foro privilegiado. Alguns ameríndios chegaram a ir pessoalmente à corte solicitar ao rei os seus privilégios (CARVALHO JÙNIOR, 2017).

Padre Figueira concluiu o seu escrito sugerindo ao rei, que, para evitar o contato dos outros europeus com os indígenas a saída plausível seria a ‘domesticação do gentio' com a vinda de missionários. Os religiosos que impediriam a produção de tabaco pelos ameríndios nas roças dos holandeses, ingleses e irlandeses. Na segunda metade do século XVII, no Cabo do Norte 
foram enviados os padres da Companhia de Jesus que em 1687 fundaram duas missões, mas os ameríndios mataram dois jesuítas na região. Uma guerra foi declarada contra os envolvidos. Alguns foram presos e outros conseguiram fugir para Guyane (atual Guiana francesa) que era território francês. Portanto, souberam fazer a leitura da realidade e identificar os conflitos entre os europeus e assim escolher o destino da fuga (NASCIMENTO, 2018).

O último combate contra os holandeses no Cabo do Norte deu-se em 1646 na tomada da casa-forte do Maricary ou Maiacaré. Em carta, o capitãomor do Pará Sebastião de Lucena de Azevedo, dirigida ao rei de Portugal em $1^{\circ}$ de janeiro de 1647, afirmou que foi informado de um naufrágio na ilha de Joanes (Marajó), e que os Aruã, "emgaibaz anajazes e outras diferentes nações que abitão nela e todos os naufragantes forao prezos e mortos pelos índios" (Carta de Sebastião de Lucena de Azevedo dirigida a D. João IV, dando conhecimento do que passa no Pará apud SARAGOÇA, 2000, p. 372). Reclamou que esses povos indígenas mantinham grandes comércios com corsários ingleses, holandeses e franceses, e os ajudavam a edificar fortalezas. O capitão-mor enviou "seis canoas com vinte portuguezes e sento e vinte Indios" (Carta de Sebastião de Lucena de Azevedo dirigida a D. João IV,..., apud SARAGOÇA, 2000, p. 372), sob o comando de Pedro da Costa Favela. Havia um pirata holandês que andava pelo Cabo do Norte chamado de Ubandregos ou Andregus, que com ajuda de quatro companheiros ingleses e franceses conservavam relações com os ameríndios. Pedro Favela conseguiu prender os 'estrangeiros' e os enviou a Belém em 1646.

A narrativa de Sebastião de Lucena de Azevedo é interessante, pois deixa entrever questões essenciais que revelam a importância dos indígenas nessas guerras na Amazônia. Pedro da Costa Favela precisava investir contra os inimigos holandeses e, pediu para isso, ao capitão-mor do Pará: “mais portugueses e gemtio pera hir cometer a fortificação que hião fazendo nos lagos de maricary no Rio chamado das Amazonas por ele a riba setemta legoas" (Carta de Sebastião de Lucena de Azevedo dirigida a D. João IV,... apud SARAGOÇA, 2000, p. 373). Saindo do Marajó, os portugueses foram para a 
região dos 'lagos de maricary' que ficava acima do rio Araguari, onde em 1687 os jesuítas fundaram uma missão e os dois padres foram mortos pelos indígenas (NASCIMENTO, 2018). Era uma região de difícil acesso e densamente povoada por vários povos (Aricoré, Maraone ou Maraunu e tantos outros). Segundo essa fonte, os holandeses em 1646 estavam construindo um forte, por isso a necessidade de mais soldados e nativos. O objetivo era expulsar os 'estrangeiros'. O próprio Sebastião de Lucena foi acompanhado de apenas de 12 portugueses, 120 indígenas, um guia inglês e um francês que haviam sido capturados. A quantidade de ameríndios deslocados para os combates era incomparavelmente maior do que os europeus, o que mais uma vez demonstrava a dependência em relação a esses indivíduos.

Sebastião de Lucena tomou a casa - forte no Maricary ou Maiacaré e no combate muitos nativos aliados dos "estrangeiros" acabaram morrendo. O capitão-mor do Pará tomou quatro grandes canoas e "simcoenta escravos e escravas vinte armas de fogo muita frecharia e arcos hum falconete de bronze e hum barril de pólvora outro de balas" (Carta de Sebastião de Lucena de Azevedo dirigida a D. João IV,... apud SARAGOÇA, 2000, p. 373), além de ter capturado 13 estrangeiros. Um detalhe fundamental é que ele justifica a vitória devido "muitos os Indios e estarem bem armados" (Carta de Sebastião de Lucena de Azevedo dirigida a D. João IV,... apud SARAGOÇA, 2000, p. 373).

Os fortes tomados pelos portugueses com a colaboração dos indígenas eram muito mais feitorias que serviam para armazenar a produção de tabaco, madeiras, urucum. Estrategicamente foram construídos próximos às aldeias, pois assim os europeus poderiam negociar com as diversas sociedades do Cabo do Norte, principalmente Tucuju, Aruã e Maraone. Cabia aos ameríndios limpar as roças e construir casas mediante pagamentos, sobretudo machado, facão, contas de vidro, espelhos. As mercadorias trazidas pelos holandeses para negociação eram chamadas de Indiaans cargasoen (HULSMAN, 2016). Lodewijk Hulsman (2016, p. 51) argumenta que: "parte do trabalho indígena provavelmente veio em forma de escravos que foram comprados dos povos vizinhos". Como citado no início deste artigo, as guerras faziam parte das 
culturas ameríndias, e os colonizadores incentivavam esses conflitos para poder comprar escravizados. Não obstante, os indígenas se aliavam aos europeus para poder vencer inimigos e se protegerem. Em relação aos produtos vindos da Europa, foram incluídos nas redes comerciais e circulavam por longas distâncias entre as diversas populações. Mas não apenas isso. Muitas mercadorias foram ressignificadas pelos nativos.

\section{Guerras entre ingleses, portugueses e indígenas}

Desde o início do século XVII, os ingleses faziam expedições pela Amazônia, no entanto, as relações com os indígenas eram esporádicas. A realidade mudou em 1619 com a criação da Amazon Company, que visava explorar a região. Vários nobres financiaram essa companhia. Roger North foi o seu principal representante e liderou as primeiras viagens oficiais. Seu interesse era comercial, sobretudo, pelas tinturas, drogas do sertão, madeiras, frutas e até pela possibilidade de encontrar minas (LIMA, 2006). Em abril de 1619, Sir Thomas Couventry, que era membro da Companhia, solicitou ao conselho do Estado inglês uma autorização do rei para utilização de navios, munições, homens e outros recursos necessários para as viagens. Nesse pedido estipulouse a área de atuação dos colonos que: “[...] deve se estender do rio Wyapoco para cinco graus sul, de qualquer parte do rio Amazonas ou chamado orelhana e para longitude terra a dentro estando limitada pelo mar [...]" (LORIMER, 1989: 195-196 apud LIMA, 2006, p. 152).

A autorização foi concedida, e a Amazon iniciou seus trabalhos na região, plantaram tabaco e cana de açúcar por meio da exploração do trabalho dos indígenas. Ao perceberam a presença inglesa, os espanhóis reclamaram ao rei inglês e por isso a viagem do capitão North foi suspensa, entretanto, uma soma elevada de recursos tinha sido investida e North argumentou ao rei que os espanhóis não possuíam presença efetiva no Cabo do Norte. Para os ingleses a ausência de ações efetivas permitia a exploração de outras nações. O rei acabou autorizando, mas devido novas pressões do governo espanhol, ele resolveu 
prender North. O capitão conseguiu partir antes de ser notificado de sua prisão e trouxe consigo dois barcos, mas o rei Jaime I se irritou e acabou com a Companhia e expediu ordens para prender North assim que parasse em qualquer porto de sua majestade. Sem o apoio oficial do governo inglês, os colonos estavam por sua própria conta. Chegaram à Amazônia e se juntaram aos holandeses e irlandeses que já plantavam tabaco com o auxílio dos indígenas há cerca de doze anos (LIMA, 2006).

Como exposto anteriormente, os ingleses construíram um forte no rio Felipe (entre os rios Matapy e Anaeurapucu) e Pedro da Costa Favela informou que havia vários europeus em contato comercial com seus aliados ameríndios no referido forte. Dessa forma, Jacome Raimundo de Noronha foi, no início de 1631, designado a ir à fortificação com o auxílio do sargento-mor Manuel Pires e o capitão Aires de Sousa Chichorro e acabaram por tomá-la mediante a rendição dos inimigos (SARAGOÇA, 2000).

Jacome Raimundo de Noronha em Relação sobre as cousas pertencentes á conservação e aumento do Estado do Maranhão afirmou o que se tem argumentado nesta pesquisa, isto é, a dependência dos europeus em relação aos indígenas. Segundo ele, "toda a defensa, e forças da Conquista do Maranhão, e Parâ, consiste no gentio, e Indios moradores naqueles grandes rios e lagos" (NORONHA, 1912, p. 38). Foi a amizade e controle desses povos que conduziu à posse da região. No referido documento, afirmou-se que, possuindo a 'amizade' deles, nenhum outro povo europeu conseguiria se apossar das 'conquistas', mas se os holandeses, ingleses ou franceses estabelecessem acordos com os nativos seria a "total destruição dos portugueses" (NORONHA, 1912, p. 38).

Jacome Noronha citou eventos no Cabo do Norte em que os portugueses com ajuda dos indígenas aliados venceram os "estrangeiros". O primeiro ocorreu em 1629 no qual o capitão Pedro Teixeira conquistou dos holandeses o forte do Torrego. Outra ação narrada ocorreu em 1631 em que ele mesmo participou como capitão-mor da tomada do forte no rio Felipe. Na ocasião, 83 "estrangeiros" morreram e 13 foram presos, ademais: "com a destruição de 
todos os gentios seus confederados, com que ficarão os mais também atemorizados" (NORONHA, 1912, p. 38-39). Nessa ação, percebe-se a estratégia lusa de aterrorizar os nativos com a força da violência. $\mathrm{O}$ detalhe desse combate foi que Jacome Noronha tinha poucos soldados lhe acompanhando e: "crefcido numero de Indios guerreiros, que fe aumentou tanto nas populofas Adeas do Camutá, que já partio dellas com trinta e feis embarcações" (BERREDO, 1749, p. 263). Dessa forma, ressalta-se a sempre oportuna presença dos indígenas guerreiros que vieram da aldeia de Cametá e com o marcante auxílio deles conseguiram vencer os ingleses em 1631.

Padre Luis Figueira em seu memorial sobre as terras e gentes do Maranhão, Grão-Pará e rio das Amazonas, escrito em 1637 ao rei Felipe IV, narrou o combate comandado por Jacome Raimundo de Noronha no rio Felipe. Os 'estrangeiros' tentaram fugir num 'pataxo' que era um navio pequeno de guerra utilizado para observar a presença de inimigos (BLUTEAU, 1789), mas os indígenas os alcançaram e os: "índios remeiros com as paz dos remos the padejarão, \& lançarão tanta agoa dentro, que lhe molharão tudo, \& não podendo usar as armas de fogo" (FIGUEIRA, 1927, p. 430). Os portugueses acabaram matando os ingleses. O jesuíta atribuiu ao ataque dos nativos nas águas a condição para vitória na batalha. É necessário esclarecer que os "índios remeiros" eram valorizados pelos europeus, pois eles sabiam navegar pelos rios, furos, igarapés, isto é, possuíam a capacidade de localização. Esses pilotos eram conhecidos como "jacumaíbas", pois utilizavam pás conhecidas como "jacumã" (CARVALHO JÚNIOR, 2017). Nem sempre aparece explicitamente na documentação, mas os remadores e guias das canoas e embarcações eram os nativos. Os "remeiros" em geral não iam de graça, mas mediante pagamentos principalmente de varas de panos que deixavam com suas mulheres e familiares nas aldeias (CARVALHO JÚNIOR, 2017).

Outro caso de guerra contra os ingleses foi a tomada do forte Cumaú, em 1632, que se localizava nas imediações de Macapá. Jacome Noronha atribuiu a conquista lusa à falta de indígenas para socorrer os ingleses que estavam no forte, e por isso ficaram desabastecidos de mantimentos o que levou 
a se entregarem. O comandante desta fortificação era o inglês Roger Fray que não estava no forte no momento do ataque, pois tinha ido buscar reforços prometidos por Londres na foz do Amazonas e sem o auxílio prometido retornou. Neste retorno travou combate com os portugueses, no qual acabou morto (BERREDO, 1749).

Os detalhes desse combate são importantes, pois revelam as presenças ameríndias. Segundo Berredo (1749, p. 268), os “Tapuyas Ingahibas [...] fe tinhaõ unido com muita parte das fuas forças para o foccorro dos Inglezes, que fe achavã̃ com hum novo Forte chamado Camaú, nas mesmas terras dos Tocujús". Os Nheengaíbas correspondiam às varias 'nações' que viviam no Marajó e, muitas vezes, entravam em conflitos entre si, pois possuíam línguas diferentes. Os povos seriam os Mamainás, Aruã, Anajás, Mapuás, Paucacás, Guajarás, Pixispixis e outros (VIEIRA, 2008). Esses indígenas fugiram dos portugueses e se aliaram com ingleses no forte Cumaú. Feliciano Coelho cercou a fortificação e encarregou o capitão Aires Chichorro de atacar com trinta soldados e duzentos e cinquenta indígenas que acabaram vencendo os ingleses. Por fim, Feliciano Coelho mandou arrasar o forte (BERREDO, 1749).

\section{Retribuições aos militares portugueses que estiveram em combates}

Alguns militares que participaram das ações de guerras contra holandeses, ingleses e irlandeses na Amazônia e especificamente no Cabo do Norte requereram e conseguiram benefícios dos governantes. Como retribuição pelos serviços prestados por Pedro Teixeira na expulsão dos "invasores", em 1640, o então governador do Estado do Maranhão e Grão-Pará, Bento Maciel Parente (o possuidor da capitania do Cabo do Norte) concedeu ao militar trezentos casais de indígenas. Esses nativos deveriam estar à disposição do referido capitão para atender as suas necessidades econômicas, ou seja, um exemplo de que os ameríndios escravizados eram ofertados como prêmios aos militares. 
Nesta 'provisão', Bento Maciel Parente fez questão de escrever sobre a necessidade dos soldados que lutaram no Cabo do Norte de receber alguma retribuição, pois há quatro anos não recebiam os pagamentos. Segundo ele, os militares pediram como pagamento indígenas da administração. Isso demonstra o quanto a força de trabalho nativo era essencial não apenas para as atividades econômicas, militares, mas também de sobrevivência na Amazônia colonial. Maciel Parente deixou claro que os nativos do Cabo do Norte tinham: "por nome os Tucujus e os Indios que entre nos e elles habitavão estarem mais alianados aos Olandezes que a nos por nos faltarem os resgates" (Provisão em que Bento Maciel Parente, governador - geral do Estado do Maranhão e GrãoPará, em nome de D. João IV, dá ao capitão Pedro Teixeira trezentos casais de Índios da administração apud SARAGOÇA, 2000, p. 319). Na perspectiva dele, os Tucujus preferiram os holandeses, pois os portugueses não tinham recursos para o 'resgate'.

$\mathrm{Na}$ Amazônia colonial, as práticas de 'guerras justas' e 'resgates' foram as fontes legais de escravização de ameríndios. As 'guerras justas' foram permitidas nas seguintes ocasiões: impedimento de propagação da fé, hostilidade contra portugueses ou amigos desses e quebra de pactos celebrados. Além disso, "os prisioneiros seriam convertidos em escravos e podiam ser vendidos em praça pública. Parte dos rendimentos pagaria o custo da guerra" (DIAS; BOMBARDI, 2016, p. 256). Outra forma legal de escravidão foram os 'resgates'. Essa forma significava o "resgate" daqueles que eram cativos de outros indígenas, ou seja, consistia em:

uma tropa liderada por um capitão, e acompanhada de um missionário, ia ao sertão e fazia alianças com certos grupos do interior para comprar seus prisioneiros de guerra, que aparecem nos registros como "peças". Esses teriam que trabalhar como escravas àqueles que pagassem pela sua captura (DIAS; BOMBARDI, 2016, p. 255-256).

Como foram 'salvos', o 'salvador' poderia se servir deles, desde que os tratassem bem e se responsabilizassem pela catequese: 
O cativeiro decorrente de resgate não é, aliás, ilimitado: uma vez pago em trabalho o preço do resgate, o cativo será livre, a não ser em alguns momentos em que se considera que tendo sido pago um preço acima do estipulado, o comprador possa valer-se dos serviços do resgatado pelo resto da vida (PERRONE-MOISÉS, 1998, p. 128).

Para Nádia Farage (1991), o resgate foi a modalidade de escravização indígena mais difundida no período pré-pombalino. Na prática as leis foram burladas por vários agentes coloniais, incluídos os missionários. A escravidão clandestina foi recorrente na Amazônia, ademais, os portugueses passaram a incentivar os conflitos interétnicos para conseguir mais escravizados. Se o Bento Maciel Parente estiver correto em sua análise, os holandeses no Cabo do Norte ofereciam melhores condições aos Tucuju. Nesse contexto, percebe-se os interesses dos nativos que negociavam seu apoio a esta ou aquela nação europeia de acordo com as intenções e acordos estabelecidos. Vale destacar que as relações eram fluidas e instáveis, ou seja, mudavam seus apoios de acordo as circunstâncias por eles avaliadas (ALMEIDA, 2010). De qualquer forma, as alianças com os indígenas no Cabo do Norte e em toda Amazônia foi indispensável, mormente nas guerras.

Bento Maciel Parente, em seu Memorial para conservar y augmentar la conquista y tierras del Marañón, y los índios que em ellas conquisto el capitán maior Bento Maciel Parente, son necessarias y convenientes las cosas siguientes escrito em 1627, propôs ao rei a divisão do Estado do Maranhão e Grão-Pará em várias capitanias. No documento, ele cita as várias potencialidades econômicas das regiões onde se estabeleceria cada capitania. Na região do Cabo do Norte, a sua proposta era que se fundasse uma e nela que se plantasse tabaco e algodão. Interessante que no cabo do Norte ele afirma a existência de duas 'províncias' conhecidas como "de los Tucuyús y Mariguins" (PARENTE, 1907, p. 186). Sua intenção era que dessa forma se pudesse povoar, fortificar e defender a região. O fato é que no decorrer do tempo a Amazônia foi dividida em capitanias reais e particulares. Coube a Bento Maciel Parente em 1637 a capitania hereditária do Cabo do Norte doada por Felipe IV 
e também o governado do Estado do Maranhão como prêmio por suas ações militares na Amazônia.

No mapa a seguir, elaborado pelo cartógrafo português João Teixeira Albernaz I e publicado em 1640 é possível perceber as divisões de parte da Amazônia em diversas províncias. Na região do atual Amapá havia as já citadas províncias dos Tucuju e dos Mariguyz ou Maranguis (veja na parte direita do mapa), mas, além disso, o português representa o espaço da 'província dos Tucujus' (que ficava da metade para o sul do território) com as presenças de casas-fortes, inclusive com a descrição e localização do "forte que tomamos dos Olandezes". Pela data, supõe-se ser o forte do Torrego. Na parte norte, tem-se a "província dos Mariguiz" que se supõe fazer referência à presença do povo Maraone.

Mapa 2: Província dos Tucuju e Mariguyz ou Maranguis (1640)

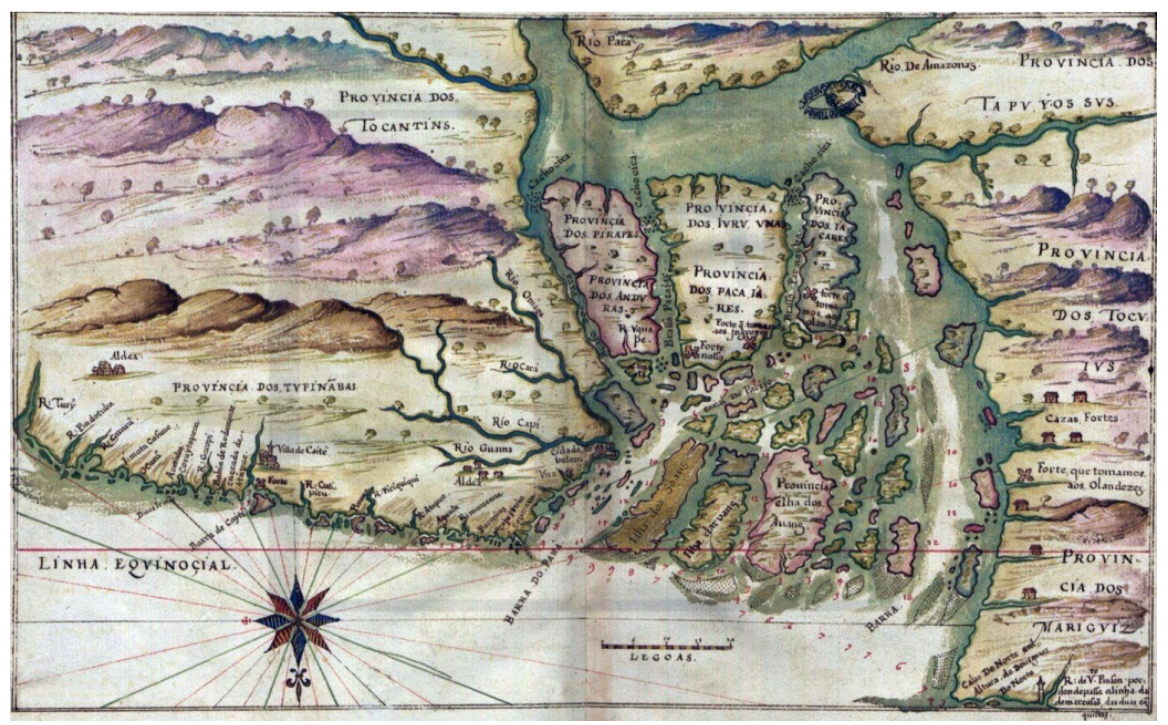

Fonte: João Teixeira Albernaz I (1640).

Alguns apontamentos sobre indígenas do Cabo do Norte na primeira metade do século XVII

O Padre Luis Figueira em seu memorial sobre as terras e gentes do Maranhão, Grão-Pará e rio das Amazonas, escrito em 1637 ao rei Felipe IV, 
informou sobre as ações dos ameríndios nas guerras contra holandeses, ingleses e irlandeses no Cabo do Norte:

A obrigação que sua Magestade lhe tem, he, que nas guerras que se offerecerão com Olandeses, \& Engreses naquelas partes, ajudão, \& ajudarão sempre aos Portugueses, assi com suas armas, como dandolhe, \& administrando-lhe todos os mantimentos de farinhas, carne, \& peixe, remando sempre as canoas de guerra, sem que sua magestade gaste nada, nem os Portugueses. E lhes fazem todos os mais serviços; \& tudo isto sem galardão (FIGUEIRA, 1927, p. 430).

Observa-se a justificativa do missionário jesuíta para que o rei concedesse possivelmente algum 'galardão' (recompensa) aos indígenas. É possível perceber nesse discurso o quanto os nativos fizeram pelos portugueses: com suas armas, a pesca, caça, produção de farinha, usando armas contra os outros europeus e sendo remadores, o que era indispensável, pois eles conheciam a geografia dos rios amazônicos.

A valorização das agências indígenas não era por apenas reconhecer a importância desses sujeitos, mas a intenção principal foi religiosa. No decorrer do documento o missionário jesuíta argumenta da carência de padres e da necessidade de envio de religiosos para converter esta "inumerável gentilidade" (FIGUEIRA, 1927, p. 431). Prossegue sugerindo ao rei que não só os nativos precisam ser socorridos espiritualmente, mas também os portugueses. A sugestão foi que se repartissem as: "aldeias e sertões por várias religiões" (FIGUEIRA, 1927, p. 431-432). As 'religiões’ significavam dividir a Amazônia para atuação das diversas ordens religiosas católicas, por exemplo, capuchos de Santo Antônio e a Companhia de Jesus.

Ainda em seu memorial, o missionário denuncia a exploração por parte dos portugueses em relação aos nativos. Diz ele que há "muitos cativeiros injustos" e exploração do trabalho com muita violência. Cita o exemplo das plantações de tabaco em que eles trabalhavam sete meses continuamente dia e noite, e recebiam como pagamento apenas quatro a duas varas de pano. Quando não apareciam no trabalho, eram penalizados com o tronco e açoite. A reação dos ameríndios era fugir, o que gerava prejuízo, pois despovoavam as aldeias e 
outros acabavam morrendo "de desgosto no mesmo serviço sem remédio algum" (FIGUEIRA, 1927, p. 431). Esse aspecto que os missionários entraram em conflitos com os colonos por conta da força de trabalho indígena será uma constante durante o período colonial na Amazônia portuguesa.

O irlandês Obrien Del Caprio fez uma viagem pela embocadura do rio Amazonas em 1621 acompanhado em uma embarcação com 124 pessoas. Seu relato é interessante, pois aponta questões fundamentais sobre as relações com os ameríndios:

[...] Sir Francisco retornando no navio dos índios, já pensando que estava ganhando amizades, construiu, não obstante para sua própria segurança e dos outros 15 cristão um forte de madeira e barro, rodeando-o com uma trincheira e para sua defesa tinha 40 mosquetes com pólvora e munição e outras armas. Esses índios lá seguiam muitos diferentes chefes, aos quais eles chamavam de bateros, e eles tinham contínuas rixas e guerras entre eles. Suas armas eram espadas de madeira, machados de pedra os quais tinham uma alça de uma pesada madeira muito dura, lanças de madeira maiores do tamanho de um homem e suas pontas eram formadas como as das flechas e em algumas delas venenosas [...]. O suplicante indo algumas vezes para ajudar os índios, ganhou a vitória para eles com mosquetes e estratégia, e através disso os ganhou para o seu lado, e os obrigou a cultivar tabaco e algodão para ele, e lhe dar comida e bebida daquela terra (LORIMER, 1989:264-265 apud LIMA, 2006, p. 159).

Esse texto revela não apenas a estratégia dos irlandeses de cuidar da defesa com a construção de um simples forte e armamentos, mas também aspectos das culturas indígenas que possuíam vários 'bateros' (líderes) e estavam constantemente em guerras. Os guerreiros utilizavam armas, tais como: machados de pedra, grandes lanças, flechas envenenadas. Outro aspecto a ser salientado, é a tática dos irlandeses de se aliarem aos nativos para derrotarem os inimigos dos indígenas e assim obrigá-los a trabalhar no cultivo de tabaco, algodão e produção de mantimentos. Obviamente que nem sempre essa tática irlandesa funcionava, pois grupos indígenas recusavam o contato e posterior aliança (LIMA, 2006).

As fontes analisadas neste artigo não se preocuparam em indicar quais as sociedades indígenas estiveram envolvidas nas guerras do Cabo do Norte na 
primeira metade do século XVII e tampouco detalhes dos modos de vida. Apenas algumas sociedades foram citadas, tais como, Tucuju, Maraon ou Maraones e Aruã que estabeleceram relações, sobretudo, com os holandeses, ingleses e irlandeses. Obviamente que existiam outros grupos, como por exemplo, os Palikur, Caripous, Aricari, Yao, Paragotos (BONILLO, 2015). Segundo Bonillo, no século XVII havia dois grupos Maraones, um estava situado entre o Cabo do Norte (o acidente geográfico no litoral) e Macapá; o outro ao norte entre os rios Uaçá e Oiapoque na fronteira com a colônia francesa. Este povo incialmente vivia entre o rio Araguari e Macapá, mas devido as pressões portuguesas, tiveram que migrar para a região do Uaçá na fronteira e no século XVIII foram para as missões jesuíticas francesas na Guyane (NASCIMENTO; DA SILVA, 2019).

Durante o século XVII, a pressão dos portugueses afetou a estabilidade local entre os grupos indígenas e provocou novas criações étnicas e, consequentemente, a reformulação geral das relações sociais interétnicas. Sabese que, por exemplo, alguns Aruã colaboraram com os portugueses na escravização de nativos, e outros adotaram a resistência militar. Outros ainda resolveram se retirar para o norte, ou seja, para a região do Oiapoque e Caiena onde a incipiente presença francesa oferecia possibilidades de negociações (BONILLHO, 2015; NASCIMENTO, 2018). Os Aruã (possivelmente de língua Aruaque) foram mencionados no final do século XVI pelo inglês Lawrence Keymis, que mencionou os Arwaos no rio Araguari. Este povo se alimentava de frutos do buriti (uma palmeira) e do pescado; e ocupava a região das pequenas ilhas da embocadura do rio Amazonas, ilhas da Caviana, Mexiana, a costa norte da ilha do Marajó e a costa continental até o Araguari (BONILLO, 2015).

Alguns Tucuju estavam no rio Jari e estiveram com os Aruã na missão fundada pelos franciscanos no século XVII. No final desse século grupos, desse povo resolveram partir para o norte, onde foram conhecidos como Tocoyenne ao se estabelecerem entre Caiena e Oiapoque. Mantiveram relações com os indígenas e com autoridades coloniais francesas que apreciavam o seu artesanato com pedras verdes. Mas antes das relações com os franceses, os 
Tucuju mantiveram contato com irlandeses, ingleses e holandeses. No rio Cajari, havia a principal plantação inglesa que foi chamada de Tilletille (plantavam tabaco), em que fizeram aliança com os Tucuju. Atualmente não há nenhum povo que se autodenomina Maraone, Aruã ou Tucuju. Esses povos ou foram extintos ou, para sobreviver, se fundiram a outros, o que parece ter ocorrido (BONILLO, 2015).

\section{Considerações finais}

Esta pesquisa debruçou-se sobre a 'fase' de conquista pelos portugueses no Cabo do Norte, isto é, na primeira metade do século XVII. Da segunda metade até o final do século XVIII, foi a 'fase' de consolidação com as construções de fortes, vilas e a fortaleza de São José de Macapá. Para a reflexão histórica sobre a conquista do território e de suas gentes, há poucos estudos e quase nada enfatizando as agências dos indígenas. Por isso, enveredou-se para o desvelamento das ações dos indígenas, sobretudo, em momentos de guerras, nas quais as alianças e técnicas de combate dos ameríndios foram fundamentais para as vitórias ou derrotas dos europeus.

As populações indígenas do Cabo do Norte despertaram os interesses comerciais, sobretudo, de holandeses, ingleses e irlandeses. As alianças com os Tucuju, Aruã, Maraone e outros foram essenciais para as guerras, comércio, trabalho e estabelecimentos de feitorias/fortificações. Nesses espaços os ameríndios aliados trabalhavam nas plantações de tabaco, algodão, urucum, mas serviam mediante trocas de mercadorias que eram importantes para ambos os povos. Abaixo se tem o mapa holandês intitulado Gviana Sive Amanzonvm Regio de autoria do Joan Blaeu produzido em 1662 na cidade de Amsterdã que indica, por exemplo, fortificações anglo-holandesas no Cabo do Norte. 
Mapa 3: Fortificações anglo-holandeses no Cabo do Norte

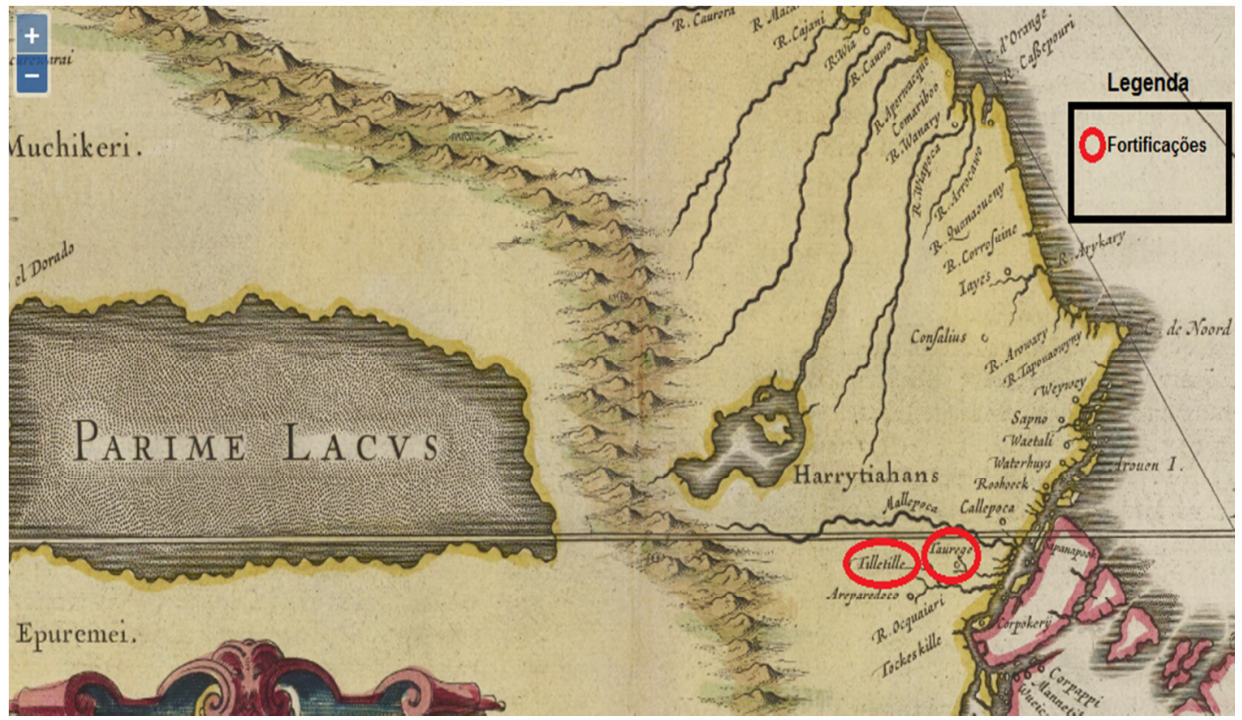

Fonte: Joan Blaeu (1662). Adaptado pelo autor. Disponível em: https://maps.nls.uk/atlas/blaeumaior/browse/11/page/157

Nesse mapa, identifica-se o forte holandês 'Tauregue' ou Torrego como conhecido nas fontes portuguesas onde se analisou a guerra e a participação indígena em sua tomada pelos lusos. Outra é 'Tilletille' que era um estabelecimento inglês localizado no rio Cajari, onde se produziam principalmente tabaco, com o trabalho dos Tucuju e Aruã (VIANNA, 1905). A curiosidade era que Macapá foi chamada pelos holandeses de Roohoeck cujo significado é 'canto vermelho' devido as barrancas vermelhas (HULSMAN, 2011).

Os fortes, casas-fortes e estabelecimentos funcionaram para além de defesa militar, ou seja, eram feitorias em que a negociação com os indígenas foi fundamental para produção no entorno e exportação para Europa. Como demonstrado ao longo deste artigo, mesmo que limitadamente, as agências nativas foram verificadas, mormente nas guerras em que as técnicas dos diversos grupos foram importantes, destaque para as flechas incendiadas que eram utilizadas para queimar as habitações no interior dos fortes, por exemplo, no Torrego. As flechas com venenos mortais, os guias e remadores foram imprescindíveis, pois eles que sabiam navegar pelos rios, furos e igarapés na 
Amazônia colonial. Portanto, nas guerras no Cabo do Norte, na primeira metade do seiscentos coube aos ameríndios um papel importante e decisivo.

É necessário explicitar que a despeito dos agenciamentos indígenas, negociações, inclusão dos europeus nas redes de comércio, conhecimentos da região os nativos saíram perdendo, pois sofreram perdas, violências e explorações. Não obstante, a história das guerras no Cabo do Norte não se resumiu apenas a isso e tampouco essas populações foram meras coadjuvantes, ou seja, mesmo que limitadamente fizeram as suas escolhas e foram sujeitos ativos.

Referências

ALBERNAZ I, João Teixeira. Dêscripção de todo o marítimo da Terra de Santa Cruz chamado vulgarmente, o Brazil. Lisboa: Arquivos Nacionais/Torre do Tombo, 1640.

ALMEIDA, Maria Regina Celestino de. Os índios na História do Brasil. Rio de Janeiro: Editora FGV, 2010.

ALMEIDA, Maria Regina Celestino de. História e antropologia. In: CARDOSO, Ciro Flamarion; VAINFAS, Ronaldo. (Orgs.). Novos domínios da História. Rio de Janeiro: Elsevier, 2012. p. 151-168.

ALMEIDA, Maria Regina Celestino de. Metamorfoses indígenas. 2. ed. Rio de Janeiro: FGV, 2013.

ALVES FILHO, Armando; SOUZA JÚNIOR, José Alves de; BEZERRA NETO, José Maia. Pontos de História da Amazônia. v 1, 3 ed. rev. ampl. Belém: Paka-Tatu, 2001.

BAENA, Antônio Ladislau Monteiro. Compêndio das eras da província do Pará. Belém: Tipografia de Santos \& Santos Menor, 1838.

BETTENDORFF, João Felipe. Crônica dos Padres da Companhia de Jesus no Estado do Maranhão. Belém: Fundação Cultural do Pará Tancredo Neves/Secretaria de Estado da Cultura, 1990.

BERREDO, Bernardo Pereira de. Annaes Históricos do Estado do Maranhaõ, em que se dá notícia do seu descobrimento, e tudo o mais que nelle tem sucedido desde $o$ ano em que foi descuberto até o de 1718. Lisboa: Oficina de Francisco Luiz Ameno, 1749. 
BLUTEAU, Rafael. Diccionario da lingua portugueza composto pelo padre D. Rafael Bluteau, reformado, e accrescentado por Antonio de Moraes Silva natural do Rio de Janeiro. Tomo II, Lisboa: Officina de Simão Thaddeo Ferreira, 1789.

BONILLO, Pablo Ibáñes. La conquista portuguesa del estuario amazónico. Tese (Doutorado em História) - Departamento de Geografía, Historia y Filosofía da Universidad Pablo de Olavide de Sevilla, Sevilla, 2015.

CARDOSO, Alírio. Canoa e arcabuz: a guerra hispano-holandesa na Amazônia (1621-1644). In: CARDOSO, Alírio, BASTOS, Carlos; NOGUEIRA, Shirley (org.). História militar da Amazônia. Curitiba: Editora CRV, 2015. p. 33-56.

CARVALHO JÚNIOR, Almir Diniz de. Índios cristãos. Curitiba: CRV, 2017.

COELHO, Mauro Cezar. O imenso Portugal. Revista Territórios e Fronteiras, Cuiabá, v. 1, n. 1, p. 263-283, jan./jun. 2008. Disponível em: http://ppghis.com/territorios\&fronteiras/index.php/v03n02/article/view/13/13.

CRUZ, Roberto Borges da. A farinha de cada dia. In: CHAMBOULEYRON, Rafael; SOUZA JUNIOR, José Alves de. (Orgs.). Novos olhares sobre a Amazônia colonial. Belém: Paka-Tatu, 2016. p. 221-238.

CUNHA, Manuela Carneiro da. Introdução a uma História indígena. In: CUNHA, Manuela Carneiro da. (org.). História dos índios no Brasil. 2. ed. São Paulo: Companhia das Letras, 1998. p. 9-24.

CUNHA, Manuela Carneiro da; CASTRO, Eduardo Viveiros de. Vingança e temporalidade. Journal de la Société des Américanistes, Paris, t. 71, p. 191208, 1985. Disponível em: https://www.persee.fr/doc/jsa_00379174_1985_num_71_1_2262

DA SILVA, Joaquim Caetano. O Oiapoque e o Amazonas [1861]. 4. ed. Tadução Ana Claúdia Grebot, Denise G. Esteves, Paulo Miceli. Campinas: Instituto de Filosofia e Ciências Humanas da Universidade Estadula de Campinas/Secretaria de Estado da Cultura do Estado do Amapá, 2010.

DIAS, Camila; BOMBARDI, Fernanda A. O que dizem as licenças? Flexibilização da legislação e recrutamento particular de trabalhadores indígenas no Estado do Maranhão (1680-1755). Revista História, São Paulo, n. 175, p. 249-280, jul./dez. 2016. Disponível em: http://www.scielo.br/pdf/rh/n175/2316-9141-rh-175-00249.pdf

DOMINGUES, Ângela. Quando os índios eram vassalos. Lisboa: Comissão Nacional para as Comemorações dos Descobrimentos Portugueses, 2000. 
FARAGE, NÁDIA. As muralhas dos sertões. Rio de Janeiro: Paz e Terra; ANPOCS, 1991.

FERNANDES, Florestan. A função social da guerra na sociedade tupinambá. 3. ed. São Paulo: Globo, 2006.

FIGUEIRA, Luis. relaçam de vários successos acontecidos no Maranham e Gram Para, assim de paz como de guerra, contra o rebelde Olandes Ingreses e Franceses, e outras nações. Annaes da Biblioteca e Arquivo Público do Pará. Tomo I, Belém: Imprensa de Alfredo Augusto Silva, 1902. Disponível em: https://ufdc.ufl.edu/AA00013075/00001/3x.

FIGUEIRA, Luis. Memorial sobre as terras e gentes do Maranhão, Grão-Pará e rio das Amazonas. Revista do Instituto Histórico e Geográfico Brasileiro. Tomo 94, vol. 148. Rio de Janeiro: Imprensa Nacional, 1927. p. 423-432.

GINZBURG, Carlo. Sinais. In: GINZBURG, Carlo. Mitos, emblemas, sinais. Tradução de Frederico Carotti. São Paulo: Companhia das Letras, 2001, p. 143179.

HENRIQUE, Márcio Couto. Sem vieira nem Pombal. Rio de Janeiro: EDUERG, 2018.

HULSMAN, Lodewijk. Swaerooch. Revista Estudos Amazônicos, Belém, v. 6, n. 1, p. 178-202. 2011.

HULSMAN, Lodewijk. Escambo e tabaco. In: CHAMBOULEYRON, Rafael; SOUZA JUNIOR, José Alves (Org.). Novos olhares sobre a Amazônia colonial. Paka-Tatu: Belém, 2016. p. 39-59.

LIMA, André da Silva. A guerra pelas almas: alianças, recrutamentos e escravidão indígena (do Maranhão ao Cabo do Norte, 1615-1647). Dissertação (Mestrado em História) - Centro de Filosofia e Ciências Humanas da Universidade Federal do Pará, Belém, 2006.

MONTEIRO, John Manuel. Armas e armadilhas. In: Novaes, Adauto. (Org.). A outra margem do ocidente. São Paulo: Companhia das Letras, 1999. p.237249.

NASCIMENTO, Bruno Rafael Machado. Ad majorem Dei gloriam. Rio de Janeiro: Autografia, 2018.

NASCIMENTO, Bruno Rafael Machado; DA SILVA, Giovani José. Sobre vivências negociadas. Habitus, Goiânia, v. 17, n. 2, p. 357-378, jul./dez. 2019. Disponível em: http://seer.pucgoias.edu.br/index.php/habitus/article/view/7627. 
NORONHA, Jacome Raimundo de. Relação sobre as cousas pertencentes á conservação e aumento do Estado do Maranhão. Revista do Instituto do Ceará, Fortaleza, ano XXVI, p. 38-44, 1912.

PARENTE, Bento Maciel. Memorial para conservar y augmentar la conquista y tierras del Marañón, y los índios que em ellas conquisto el capitán maior Bento Maciel Parente, son necessarias y convenientes las cosas siguientes. Revista Trimestral do Instituto do Ceará, Fortaleza, ano XXI, p. 182-188, 1907.

PERRONE-MOISÉS, Beatriz. Índios livres e índios escravos. In: CUNHA, Manuela Carneiro da (org.). História dos índios no Brasil. São Paulo: Companhia das Letras; Secretaria municipal de cultura, 1998. p. 115- 132.

REIS. Arthur Cezar F. Território do Amapá. Rio de Janeiro: Imprensa Nacional, 1949.

REIS. Arthur Cezar Ferreira. Limites e demarcações na Amazônia brasileira. 2. ed. v.1. Belém: SECULT, 1993.

RIO BRANCO, Barão do. Obras do barão do Rio Branco III. Brasília: Fundação Alexandre de Gusmão, 2012.

SARAGOÇA, Lucinda. Da << Feliz Lusitânia >> aos confins da Amazônia (1615-62). Lisboa-Santarém: Edições Cosmos - Câmara Municipal de Santarém, 2000.

VIANA, Wania Alexandrino. "Porque sem eles [índios] se não á de se defender". In: DA SILVA, Giovani; DA SILVA, Cleube. Protagonismos indígenas na História do Norte do Brasil. Palmas: Nagô Editora, 2018. p. $137-154$.

VIANNA, Arthur. As fortificações da Amazônia I - As fortificações do Pará. Annaes da Biblioteca e Arquivo Público do Pará. Tomo IV, Belém: Instituto Lauro Sodré, 1905. p. 227-302.

VIEIRA, Antônio. Cartas. Tomo I. São Paulo: Editora Globo, 2008.

Recebido em: 14 de abril de 2020

Aceito em: 14 de maio de 2021 